\title{
Palmitoleic Acid Infusion Alters Circulating Glucose and Insulin Levels
}

\author{
Long NM, Burns TA, Volpi Lagreca G, Alende M and Duckett SK
}

Department of Animal and Veterinary Sciences, Clemson University, Clemson, SC 29634, USA

*Corresponding author: Susan K Duckett, Department of Animal and Veterinary Science, 146 Poole Agricultural Center, Box 340311, Clemson, SC 29634-0311, USA, Tel: 864-656-5151; Fax: 864-656-3131; E-mail: sducket@clemson.edu

Received date: May 02, 2014; Accepted date: June 23, 2014; Published date: June 26, 2014

Copyright: (C) 2014 Long NM, et al. This is an open-access article distributed under the terms of the Creative Commons Attribution License, which permits unrestricted use, distribution, and reproduction in any medium, provided the original author and source are credited.

\begin{abstract}
Objectives: The objectives of these studies are to evaluate: 1) uptake of a pulse dose of ${ }^{13} \mathrm{C} 16: 1$ cis-9 at varying levels into the blood and 2) glucose and insulin changes after pulse dose of 0 or $5 \mathrm{mg} \mathrm{C16:1} \mathrm{cis-9/kg} \mathrm{body} \mathrm{weight}$ (BW) under challenge conditions in obese lambs.

Methods: Two experiments were conducted to evaluate uptake of $\mathrm{U}-{ }^{13} \mathrm{C} 16: 1 \mathrm{cis}-9$ into the blood and changes in glucose and insulin under challenges. In the first experiment, lambs $(67.4 \pm 1.4 \mathrm{~kg} \mathrm{BW}$, n=3) received jugular catheters and were used in a $3 \times 3$ Latin square. Treatments were 0,2 or $5 \mathrm{mg} / \mathrm{kg} \mathrm{BW}$ of U-13 C $16: 1$ cis-9 in $40 \%$ (wt/v) ethanol and blood samples were collected post infusion for glucose, fatty acid and insulin analyses. In the second experiment, lambs $(86.7 \pm 1.5 \mathrm{~kg} \mathrm{BW} ; \mathrm{n}=4)$ received jugular catheters. Treatments were $0 \mathrm{or} 5 \mathrm{mg} / \mathrm{kg} \mathrm{BW}$ of C16:1 in 40\% (wt/v) ethanol immediately followed by a glucose $(0.25 \mathrm{~g} / \mathrm{kg})$ or insulin $(0.02 \mathrm{mlU} / \mathrm{kg}) \mathrm{challenge}$.

Results: Both the 2 and $5 \mathrm{mg} / \mathrm{kg} \mathrm{BW}$ dose of $\mathrm{U}-{ }^{13} \mathrm{C} 16: 1$ cis-9increased $(\mathrm{P}=0.003) \mathrm{C} 16: 1$ cis-9in serum compared to $0 \mathrm{mg} / \mathrm{kg} \mathrm{BW}$. The $5 \mathrm{mg} / \mathrm{kg}$ BW dose had a greater magnitude of increase for serum $\mathrm{C} 16: 1$ and resulted in increased whole blood glucose levels for first $60 \mathrm{~min}$ and altered insulin levels for first $30 \mathrm{~min}$. During the glucose tolerance test, $C 16: 1$ bolus infusion increased $(P=0.02)$ peak, overall, and area under the curve for plasma glucose levels. During the insulin challenge, $\mathrm{C} 16: 1$-treated lambs had increased glucose levels $(\mathrm{P}=0.04)$ and peak, overall, and area under the curve plasma insulin $(P=0.0001)$.
\end{abstract}

Conclusion: Palmitoleic acid infusion results in immediate uptake and clearance of serum palmitoleic acid, increases plasma glucose levels, and alters circulating insulin levels.

Keywords: Palmitoleic acid; Glucose; Insulin; Stable isotope; Fatty acid

\section{Introduction}

Palmitoleic (C16:1 cis-9) acid is an omega-7 monounsaturated fatty acid that is produced via desaturation of palmitic acid by stearoyl-CoA desaturase (SCD-1). Palmitoleic acid has been proposed to function as a lipokine, a fatty acid that stimulates muscle insulin action [1]. Previous research [2,3] has shown that palmitoleic (C16:1 cis-9) acid addition to bovine primary adipocytes decreases lipogenesis and increases $\beta$-oxidation. Cao et al. [1] reported exogenous administration of palmitoleic acid (C16:1 cis-9) decreased lipogenesis in liver and increased insulin sensitivity in skeletal muscle of mice.

Glucose and insulin regulation in animals and humans is interplay between insulin sensitivity, how responsive a cell or tissue is to insulin binding, and responsiveness of the post receptor signing events [4]. Ruminants are less insulin sensitive compared to monogastrics [5]. The insulin resistance in ruminants has been attributed to decreased activity of glucose transporter proteins fusing to the plasma membrane of muscle during insulin stimulation [6]. Dietary lipids like fish oil, high in long-chain n-3 polyunsaturated fatty acids, increased tissues response to insulin (insulin sensitivity) in rats, miniature pigs and lambs [7-10]. Fish oil infused in the abomasum of steers resulted in increased insulin sensitivity [11]. These differences in insulin sensitivity appears to be due to longchain n-3 polyunsaturated fatty acids since feeding an saturated fatty acids did not result in changes in insulin and glucose responses [12]. Therefore it should be expected that other unsaturated fatty acids could have effects on glucose and insulin regulation in ruminants. The objectives of these studies are to evaluate: 1)uptake of a pulse dose of ${ }^{13} \mathrm{C} 16: 1$ cis-9 at varying levels into the blood and 2) glucose and insulin changes after pulse dose of 0 or 5 mg C16:1 cis-9/kg BW under challenge conditions in finished lambs.

\section{Methods}

\section{Animals}

All experimental procedures involving animals were reviewed and approved by the Clemson University Institutional Animal Care and Use Committee.

Experiment 1: Three Southdown yearling wethers (14 months of age; $67.4 \pm 1.4 \mathrm{~kg} \mathrm{BW}$ ) were used in a 33 Latin square design. Animals were fed approximately $2 \mathrm{~kg}$ per day of a high energy, corn-based diet (give Southern State Hi-Energy Lamb starter-Grower, Richmond, VA) designed to meet or exceed NRC (2007) requirements for finishing lambs in addition to ad libitum access to Coastal Bermudagrasshay $(11.6 \% \mathrm{CP}, 1.36 \mathrm{McalNEm} / \mathrm{kg}$, and $37.1 \% \mathrm{ADF}$ on a $\mathrm{DM}$ basis) and water. Lambs were housed at the Clemson University Brick Barn (Pendleton, SC) and were maintained in individual pens (1.49 $\mathrm{m}_{2}$ floor space) during each experimental challenge. Treatments were a pulse dose infusion of $0(\mathrm{CON}), 2$ or $5 \mathrm{mg} / \mathrm{kg}$ BW of $\mathrm{U}_{-}{ }^{13} \mathrm{C} 16: 1$ 
cis-9 (Isotech, Inc., Miamisburg, OH) in 40\% ethanol (wt/vol). Blood samples $(\sim 6 \mathrm{ml})$ were collected at $-30,15$, and 0 minutes before pulse lipid infusion, every 15 minutes for 2 hours, and then every 30 minutes for an addition hour post infusion. Immediately after blood collection, whole blood glucose was measured via Alpha Trak handheld glucometer (Abbot; North Chicago, IL) in duplicate (2.2\% CV between duplicate readings) as part of normal infusion protocols. Lambs were fasted $12 \mathrm{~h}$ prior to each treatment with 10 days rest between tests.

Experiment 2: Four Southdown yearling wethers (18 months of age; $86.7 \pm 1.7 \mathrm{~kg} \mathrm{BW}$ ) estimated to have at least $0.91 \mathrm{~cm}$ backfat, which equates to about $30 \%$ body fat, were used in this study to evaluate changes in glucose and insulin under challenge. Animals were housed and fed as previously described above before and during each experimental challenge. Lambs were fasted $18 \mathrm{~h}$ prior to each treatment with $44 \mathrm{~h}$ rest between tests. Treatments were a pulse dose infusion of 0 (CON) or $5 \mathrm{mg} / \mathrm{kg} \mathrm{BW}$ of C16:1 (Sigma-Aldrich, $>98.5 \%$ C16:1 cis-9) in $40 \%$ (wt/vol) ethanol in combination with intravenous administration of $0.25 \mathrm{~g}$ glucose $/ \mathrm{kg} \mathrm{BW}$ (intravenous glucose tolerance test, IVGTT; 50\% dextrose solution; VedcoInc, ST. Jospeh, MO) at 0 min on the first 2 test days consistent with a crossover design. Ethanol

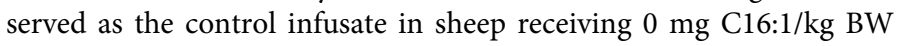
dose. The crossover design was repeated for 2 additional test days with lambs receiving 0 or $5 \mathrm{mg} / \mathrm{kg}$ BW C16:1 pulse dose in combination with an insulin challenge (IC; $0.02 \mathrm{mIU} / \mathrm{kg}$ BW, Sigma-Aldridge, St. Louis, MO). On each test day, blood samples $(6 \mathrm{ml})$ were collected at -15 min, immediately prior to infusion, and $2,4,6,8,10,12,15,20,25$, $30,35,40,50,60,70,80,100,120$, and $150 \mathrm{~min}$ after C16:1 infusion.

A 16-ga indwelling jugular catheter (Abbocath, 16 gauge, Abbott Laboratories, North Chicago, IL, USA) was inserted and sutured to the skin $1 \mathrm{~d}$ prior to initiation of the first test for substrate administration and blood sampling. Catheters were kept patent with $4 \%$ sodium citrate in sterile saline (Jorgensen Laboratories, Inc., Loveland, CO). Immediately after each sample collection, whole blood was placed into serum and heparinized vacuum tubes. Serum tubes were allowed to clot for $2 \mathrm{~h}$ at room temperature, held overnight at $4^{\circ} \mathrm{C}$, and centrifuged at 2,000 $\mathrm{x}$ g for $15 \mathrm{~min}$ to obtain serum. Heparinized tubes were immediately centrifuged at 2,000 $\mathrm{x}$ g for $15 \mathrm{~min}$. Plasma aliquots were collected and frozen at $-20^{\circ} \mathrm{C}$ for later analysis of glucose, insulin, and fatty acid concentrations. Serum and plasma aliquots were collected and frozen at $-20^{\circ} \mathrm{C}$ for subsequent analyses of long-chain fatty acids (serum) and glucose and insulin (plasma).

\section{Fatty acids}

For fatty acid analysis, serum aliquots ( $1 \mathrm{~mL}$ in duplicate) from each lamb and time point were lyophilized (Lab Conco, Kansas City, MO) and transmethylated according to Park and Goins [13]. Fatty acid methyl esters (FAME) were analyzed using an Agilent 6850 gas chromatograph (GC) equipped with an Agilent 7673A automatic sampler (Agilent Technologies, Inc., Santa Clara, CA). Separations were accomplished using a 100-m Supelco SP-2560 (Supelco, Inc., Bellefonte, PA) capillary column $(0.25 \mathrm{~mm}$ i.d. and $0.20 \mu \mathrm{m}$ film thicknesses) according to Duckett et al. [14]. Individual fatty acids were identified by comparison of retention times with known standards (Sigma, St. Louis, MO; Matreya, Pleasant Gap, PA). Fatty acids were quantified by incorporating an internal standard, methyl tricosanoic (C23:0) acid, into each sample during methylation and expressed as a weight percentage.

For stable isotope analyses, FAME samples were analyzed with an Agilent 6890N GC equipped with an Agilent 5973 mass spectrometer
(MS) using a 100-m Varian CP7489 (Varian Instruments Inc., Walnut Creek, CA $)$ capillary column $(0.25 \mathrm{~mm}$ i.d. and $0.20 \mu \mathrm{m}$ film thickness). Samples were run in chemical ionization mode with $\mathrm{He}$ as the carrier gas and $\mathrm{CH} 4$ as the reagent gas.Ions of mass-to-charge ratio $(\mathrm{m} / \mathrm{z}) 268(\mathrm{~m})$ and $284(\mathrm{~m}+16)$ were selectively measured to calculate the isotopic enrichment of C16:1 in serum. Results were calculated according to [15] and presented as molar percent excess.

\section{Glucose and Insulin}

For glucose and insulin concentration during the IVGTT and IC in experiment 2 the $-15,0,4,8,10,15,20,25,30,40,50,60,70,80,100$, 120 , and 150 minutes samples were analyzed and all serum samples were analyzed for insulin concentrations in experiment 1 . Glucose was measured colorimetrically in triplicate using Liquid Glucose Hexokinase Reagent (Pointe Scientific Inc., Canton, MI), as described by Long and Schafer (2013), and a Bio Tek Synergy HT (Winooski, VT) microplate reader. Mean intra- and inter assay CV were 3.3 and $6.3 \%$, respectively. Insulin was measured in duplicate by commercial RIA [16; Siemens Medical Solutions Diagnostics, Los Angeles, CA], with intra-assay CV of $8.05 \%$, and a sensitivity of $1.5 \mu \mathrm{IU} / \mathrm{mL}$.

\section{Statistics}

For experiment 1, serum U- ${ }^{13} \mathrm{C} 16: 1$ cis-9 molar percent excess, insulin concentration, whole blood glucose, and a calculated insulin to glucose ratio were analyzed as a repeated measures using the Proc Mixed procedure of SAS 9.2 (SAS Institute Inc., Cary, NC) with treatment, time and the two-way interaction as fixed effects and period (order of lipid dosing) as a random effect. Post hoc t-tests were performed to determine treatment differences within a time point. For experiment 2, Graph pad Prism (Graph Pad Software Inc, La Jolla, CA) was used to calculate the area under the curve (AUC) for plasma glucose and insulin response curves during the IVGTT and IC. Plasma metabolite and insulin concentrations were analyzed as a repeated measures using Proc MIXED procedure of SAS using the previously mentioned model. Each AUC for the challenges were analyzed using Proc MIXED procedure of SAS with treatment in the model and period as a random effect. In addition, insulin to glucose ratio was calculated from the AUC from both the IVGTT and IC for each animal treatment combination as previously described [17] and this value was analyzed using the Proc MIXED procedure of SAS with treatment in the model and period as a random effect. Data are presented as least square means \pm SEM, and differences considered significant at $\mathrm{P}<0.05$, with a tendency at $\mathrm{P}<0.10$.

\section{Results}

\section{Palmitoleic Acid Uptake}

Serum concentrations of palmitoleic (C16:1 cis-9) acid and enrichment of $\mathrm{U}^{13} \mathrm{C} 16: 1$ cis 9 are shown in Figure 1a. Serum C16:1 cis-9 levels peaked $(\mathrm{P}<0.01)$ at $15 \mathrm{~min}$ and returned to baseline levels by $30 \mathrm{~min}$ post pulse dose. These results show that exogenous palmitoleic acid is quickly removed $(<30 \mathrm{~min})$ from the blood after a single pulse dose. Dosage levels, 2 and $5 \mathrm{mg} / \mathrm{kg}$ BW C16:1 cis-9, increased the percentage of C16:1 cis- 9 in serum; however, the magnitude of the increase was greater for $5 \mathrm{mg} / \mathrm{kg}$ BW (3\% of total) than for $2 \mathrm{mg} / \mathrm{kg} \mathrm{BW}$ (1.5\% of total). Serum U- ${ }^{13} \mathrm{C} 16: 1$ cis- 9 as a molar $\%$ excess increased $(\mathrm{P}<0.05)$ above baseline at $15 \mathrm{~min}$ post pulse dose (Figure 1b). For the $2 \mathrm{mg} / \mathrm{kg}$ BW dose, serum U- ${ }^{13} \mathrm{C} 16: 1$ cis-9 
Citation: Long NM, Burns TA, Volpi Lagreca G, Alende M, Duckett SK (2014) Palmitoleic Acid Infusion Alters Circulating Glucose and Insulin Levels. J Metabolic Synd 3: 148. doi:10.4172/2167-0943.1000148

Page 3 of 6

remained elevated $(\mathrm{P}<0.05)$ above baseline for $60 \mathrm{~min}$. For the $5 \mathrm{mg} / \mathrm{kg}$ BW dose, serum $\mathrm{U}^{13} \mathrm{C} 16: 1$ cis-9 remained elevated $(\mathrm{P}<0.05)$ above baseline for $180 \mathrm{~min}$ post pulse dose.

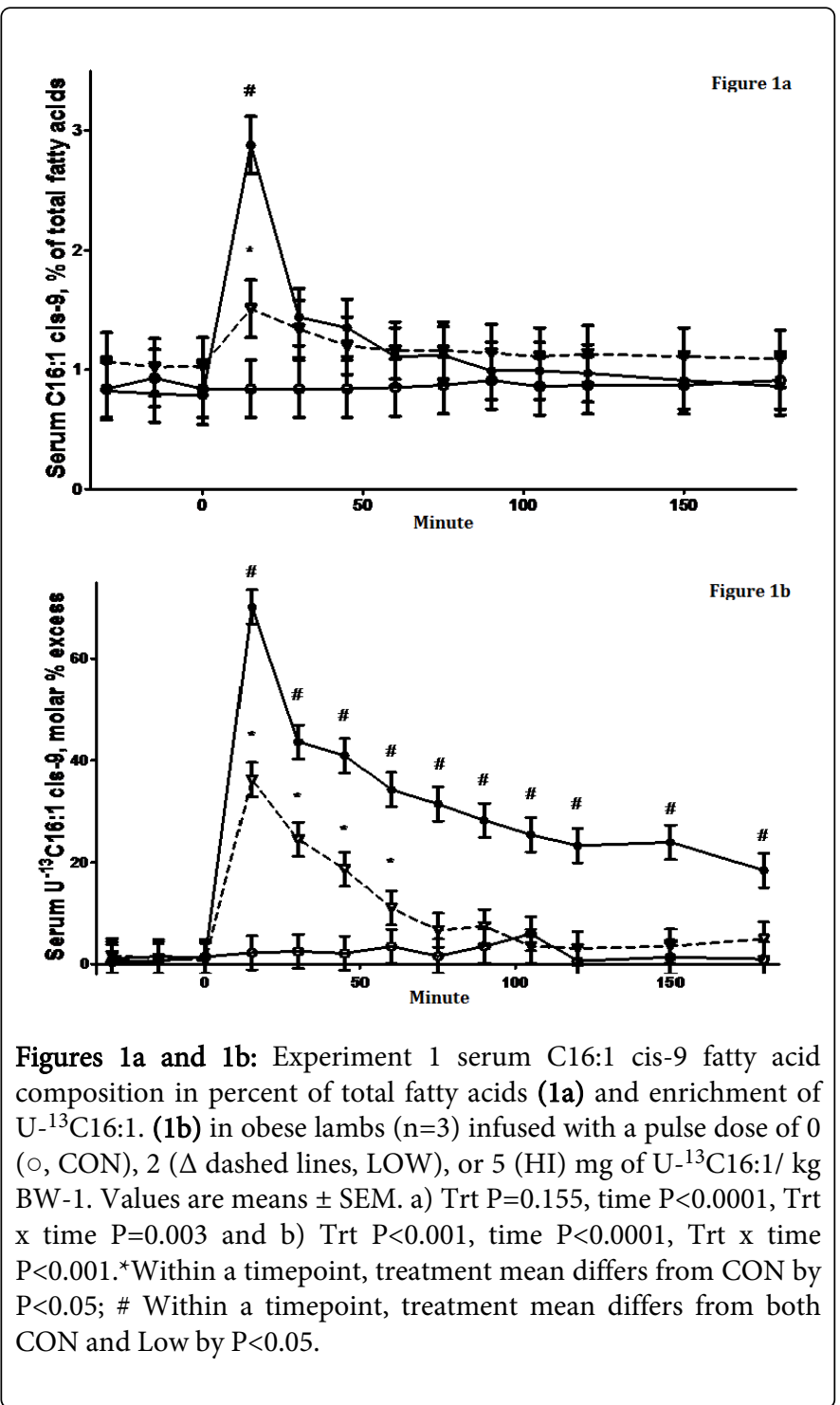

\section{Glucose and Insulin}

Whole blood glucose concentrations increased $(\mathrm{P}<0.05)$ in the 5 $\mathrm{mg} / \mathrm{kg}$ BW dose of $\mathrm{U}_{-}{ }^{13} \mathrm{C} 16: 1$ cis-9at 15 to 60 minutes post bolus infusion (Figure 2a). For serum insulin, there was a treatment by time interaction $(\mathrm{P}=0.039$; Figure $2 \mathrm{~b})$. Serum insulin levels in $5 \mathrm{mg} / \mathrm{kg} \mathrm{BW}$ U- ${ }^{13} \mathrm{C} 16: 1$ cis-9 treated animals were elevated over controls at $15 \mathrm{~min}$ post doing; however, serum insulin levels decreased below controls at $30 \mathrm{~min}$ post dosing. There were no changes in whole blood plasma glucose or serum insulin levels at the $2 \mathrm{mg} / \mathrm{kg}$ dose of $\mathrm{U}^{-13} \mathrm{C} 16: 1$ cis-9. These alterations in glucose and insulin reduced $(\mathrm{P}<0.05)$ the insulin to glucose ratio from 30 to $75 \mathrm{~min}$ post infusion in the $5 \mathrm{mg} / \mathrm{kg}$ dose of C16:1 cis-9 group compared to the other two doses $(0$ and $2 \mathrm{mg} / \mathrm{kg}$ BW; Figure 2c).
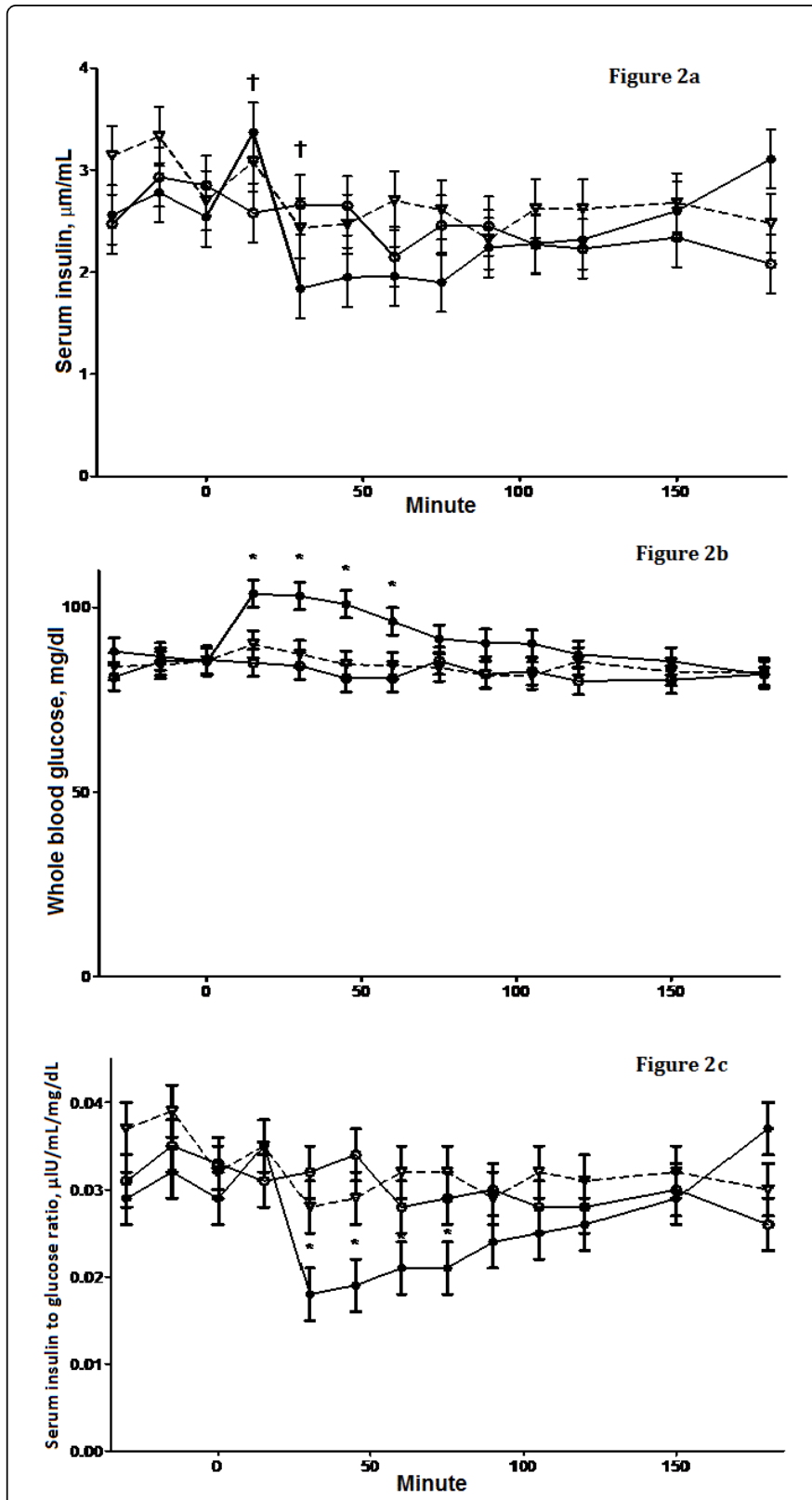

Figures 2a-2c: Experiment 1 whole blood glucose (2a), serum insulin (2b) and serum insulin to whole blood glucose ratio (2c) in obese lambs $(n=3)$ infused with a pulse dose of $0(0, \mathrm{CON}), 2(\Delta$ dashed lines, LOW), or $5(, \mathrm{HI}) \mathrm{mg}$ of $\mathrm{U}_{-}{ }^{13} \mathrm{C} 16: 1 / \mathrm{kg}$ BW-1.Values are means \pm SEM. a) Trt $\mathrm{P}=0.023$, time $\mathrm{P}=0.033$, Trt $\mathrm{x}$ time $\mathrm{P}=0.165$; b) Trt $\mathrm{P}=0.35$, time $\mathrm{P}=0.005$, Trt $\mathrm{x}$ time $\mathrm{P}=0.039$; and $\mathrm{c}$ ) Trt $\mathrm{P}=0.023$, time $\mathrm{P}<0.0001$, Trt $\mathrm{x}$ time $\mathrm{P}=0.038$. ${ }^{*}$ Within $\mathrm{a}$ timepoint, treatment mean differs from $\mathrm{CON}$ and LOW by $\mathrm{P}<0.05$; longitudinal comparisons $\mathrm{P}<0.05$ from the preceding period are indicated by $\dagger$ within the $\mathrm{HI}$ dose.

\section{Glucose Challenge}

Serum C16:1 cis-9 as a percent of total serum fatty acids increased $(\mathrm{P}<0.01)$ from 2 to $15 \mathrm{~min}$ post dosing with $5 \mathrm{mg} / \mathrm{kg}$ BW bolus infusion of C16:1 cis-9 associated with the glucose administration during 
Citation: Long NM, Burns TA, Volpi Lagreca G, Alende M, Duckett SK (2014) Palmitoleic Acid Infusion Alters Circulating Glucose and Insulin Levels. J Metabolic Synd 3: 148. doi:10.4172/2167-0943.1000148

Page 4 of 6

IVGTT (Figure 3a). In response to the $5 \mathrm{mg}$ bolus infusion of C16:1 cis-9, plasma glucose was elevated at $10 \mathrm{~min}$ and from 30 to $150 \mathrm{~min}$ post infusion compared to the control group (Figure $3 \mathrm{~b}$ ). This difference was confirmed by the $5 \mathrm{mg}$ bolus infusion of C16:1 cis 9 having a greater $(\mathrm{P}=0.01)$ AUC for plasma glucose during IVGTT. There was no difference $(\mathrm{P}=0.95)$ in plasma insulin between treatments during the IVGTT (Figure 3c). The AUC for plasma insulin was also similar $(\mathrm{P}=0.89)$ between treatments. The insulin to glucose ratio during the IVGTT was reduced $(\mathrm{P}=0.005)$ in the treated lambs compared to control ( $0.19 \pm 0.03$ vs $0.29 \pm 0.03$, respectively).

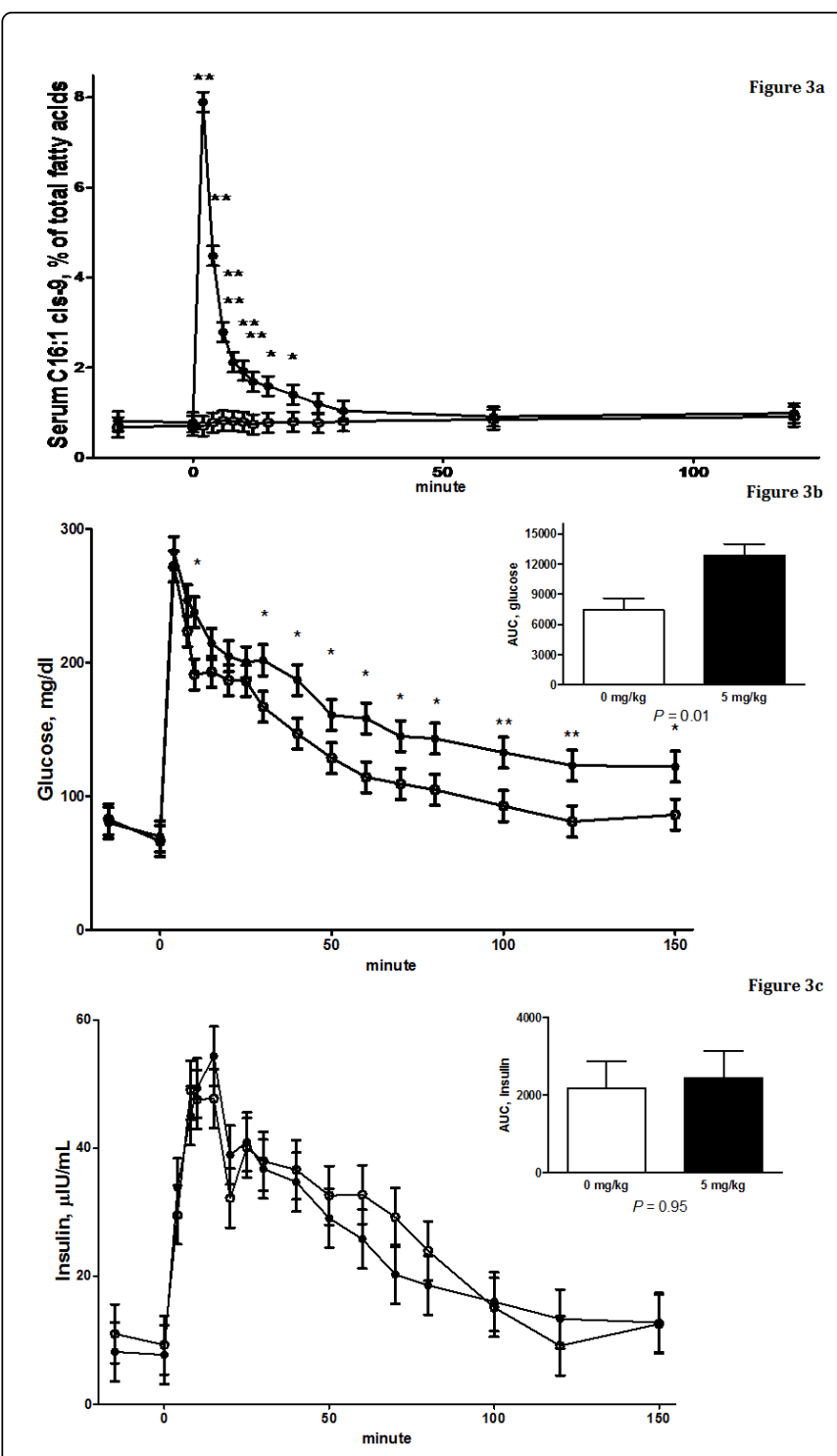

Figure 3: Experiment 2 plasma palmitoleic acid. (a) glucose (b) and insulin (c) responses during an intravenous glucose tolerance test in obese lambs pulse infused with $0(0, \mathrm{n}=4)$ or $5 \mathrm{mg} / \mathrm{kg} \mathrm{BW}$ of $\mathrm{C} 16: 1(\bullet, \mathrm{n}=4)$. Values are means \pm SEM. a) Trt $\mathrm{P}<0.0001$, time $\mathrm{P}<0.0001$, Trt $\mathrm{x}$ time $\mathrm{P}<0.0001$; b) Trt $\mathrm{P}=0.951$, time $\mathrm{P}<0.0001$, Trt $\mathrm{x}$ time $\mathrm{P}=0.952$; and c) Trt $\mathrm{P}=0.91$, time $\mathrm{P}<0.0001$, Trt $\mathrm{x}$ time $\mathrm{P}=0.95$. * Mean differences $(\mathrm{P}<0.05)$ and ${ }^{* *}$ mean differences $(\mathrm{P}<0.01)$ at a specific time point between treatments.

\section{Insulin Challenge}

Serum C16:1 cis-9 as a percent of total serum fatty acids increased $(\mathrm{P}<0.05)$ in response to a $5 \mathrm{mg}$ bolus infusion of $\mathrm{C} 16: 1$ cis 9 from 2 to $30 \mathrm{~min}$ post infusion associated with the insulin administration during IC (Figure 4a). During the IC, plasma glucose was increased $(\mathrm{P}<0.05)$ at 20, 25 and $100 \mathrm{~min}$ post infusion in the $5 \mathrm{mg}$ bolus infusion of C16:1 cis-9 compared to control (Figure $4 \mathrm{~b}$ ). There was an overall increase $(\mathrm{P}=0.04)$ in plasma glucose AUC in the $5 \mathrm{mg}$ bolus infusion of $\mathrm{C} 16: 1$ cis-9 compared to control AUC for plasma glucose during IC. Plasma insulin was increased $(\mathrm{P}<0.05)$ initially $(2 \mathrm{~min}$. post dosing $)$ and remained elevated through $15 \mathrm{~min}$ in the $5 \mathrm{mg}$ bolus infusion of C16:1 cis-9 compared to control (Figure 4c). There was increased plasma insulin AUC during the IC in the $5 \mathrm{mg} / \mathrm{kg}$ treated group compared to control $(\mathrm{P}=0.02)$. The insulin to glucose ratio during the IC was similar $(\mathrm{P}=0.62)$ in the treated lambs compared to control $(0.09 \pm 0.01$ vs. $0.09 \pm 0.01$, respectively).
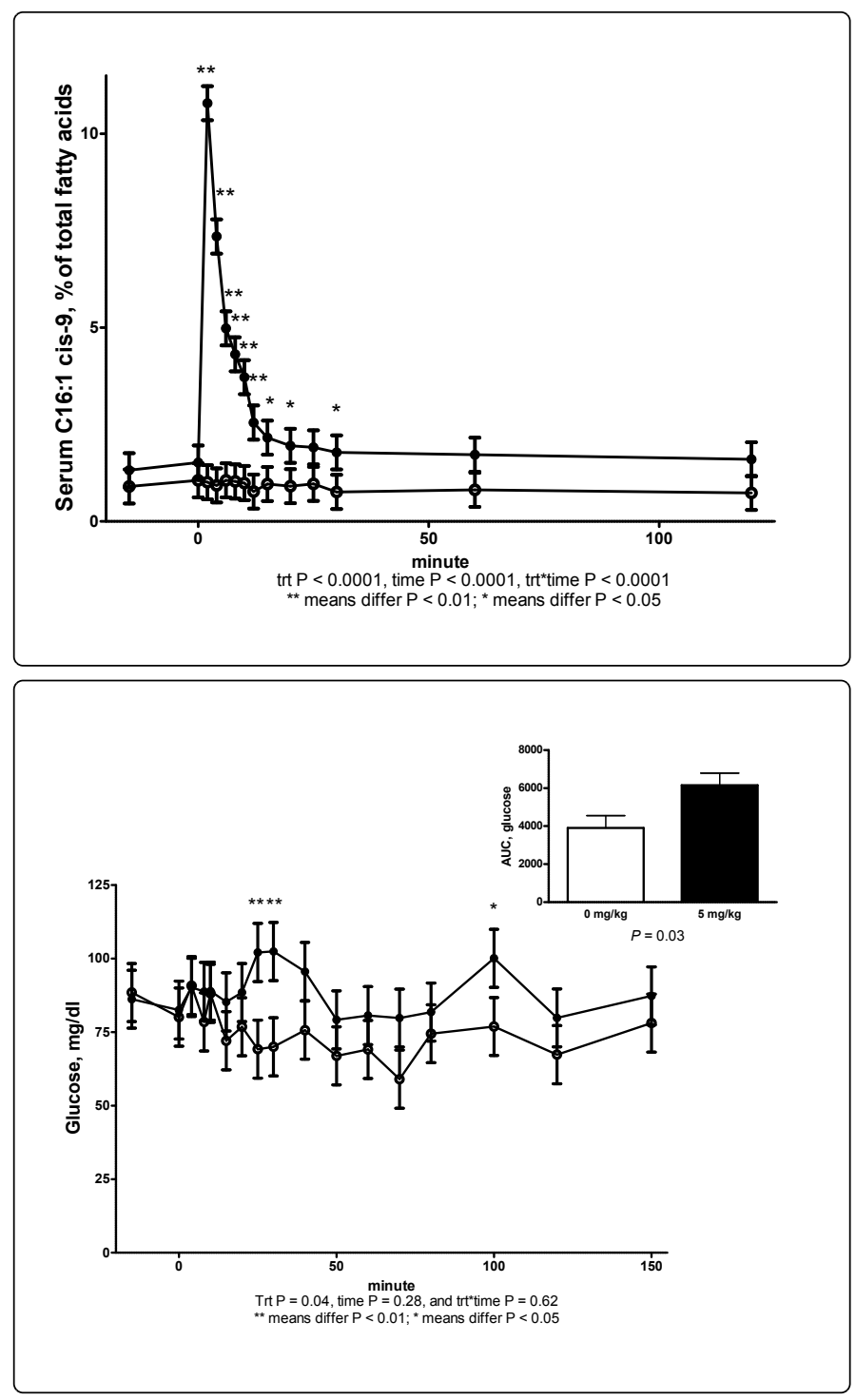


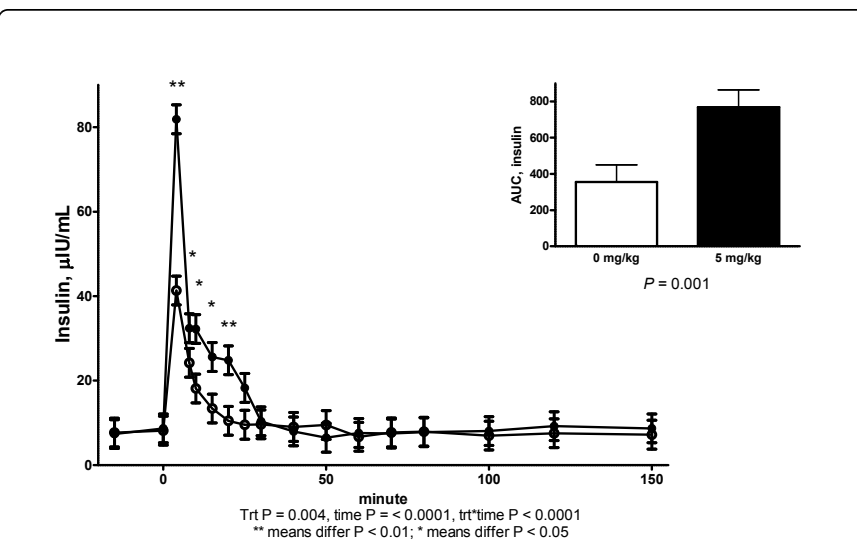

Figure 4: Experiment 2 plasma palmitoleic acid (a), glucose (b) and insulin (c) responses during an intravenous insulin challenge in obese lambs pulse infused with $0(0, \mathrm{n}=4)$ or $5 \mathrm{mg} / \mathrm{kg}$ BW of C16:1 $(\bullet, \mathrm{n}=4)$. Values are means \pm SEM. a) Trt $\mathrm{P}<0.0001$, time $\mathrm{P}<0.0001$, Trt $\mathrm{x}$ time $\mathrm{P}<0.0001 ; \mathrm{b}) \operatorname{Trt} \mathrm{P}=0.04$, time $\mathrm{P}=0.28$, Trt $\mathrm{x}$ time $\mathrm{P}=0.62$; and c) Trt $\mathrm{P}=0.004$, time $\mathrm{P}<0.0001$, Trt $\mathrm{x}$ time $\mathrm{P}<0.0001 .{ }^{*}$ Mean differences $(\mathrm{P}<0.05)$ and ${ }^{\star \star}$ mean differences $(\mathrm{P}<0.01)$ at a specific time point between treatments.

\section{Discussion}

The objectives of this research were to evaluate uptake of a pulse dose of ${ }^{13} \mathrm{C} 16: 1$ cis-9 at varying levels into the blood and changes in glucose and insulin after pulse dose of 0 or $5 \mathrm{mg} \mathrm{C16:1} \mathrm{cis-9/kg} \mathrm{BW}$ under challenge conditions in finished lambs. Palmitoleic (C16:1 cis-9) acid is an omega-7 monounsaturated fatty acid that is endogenously produced via de-saturation of palmitic acid by SCD-1. Dietary supply of palmitoleic acid is very low as sources of it in the diet are limited. This research shows that palmitoleic acid, given as a pulse-dose infusion in sheep, is rapidly taken up in the blood stream and returns to baseline levels by 30 minutes post dosing. The magnitude of response was dependent on dose level administered with $5 \mathrm{mg} / \mathrm{kg} \mathrm{BW}$ dose resulting in a greater peak of C16:1 percentage than $2 \mathrm{mg} / \mathrm{kg}$ BW. The level of palmitoleic acid in serum of normal sheep is very low ( $<1 \%$ of total fatty acids). Therefore, we utilized $\mathrm{U}-{ }^{13} \mathrm{C} 16: 1$ cis-9 as a tracer so we could specifically measure uptake of this labeled, exogenous fatty acid in the bloodstream. Based on the results, serum palmitoleic acid levels were elevated for a longer time period than could be determined without the use of the stable isotope. Palmitoleic acid concentration was elevated above baseline for 60 and 180 minutes post dosing for 2 and $5 \mathrm{mg} / \mathrm{kg}$ BW dose, respectively. Similarly, Persson et al. [15] reported a rapid uptake of free fatty acids into circulation using stable isotope labelled palmitic acid. In bovine adipocytes, palmitoleic acid uptake into the cell responds in a dose responsive manner with maximal inhibition of lipogenesis and desaturation at $150 \mu \mathrm{M}$ [3]. This reduction of lipogenesis and desaturation was the result of down regulation of fatty acid synthase (FASN) and stearoyl-CoA desaturase (SCD1), respectively.

There clearly appears to be different effects of the palmitoleic acid pulse dose infusion on plasma glucose and insulin responses depending on whether the animal was in a hyperglycemic or normal glycemic state in the current studies. In all experiments, palmitoleic acid infusion at the $5 \mathrm{mg} / \mathrm{kg}$ BW level resulted in increased plasma glucose above the control $(0 \mathrm{mg} / \mathrm{kg}$ BW C16:1. During normal glycemic state (Expt. 1) and under IC, serum insulin levels were elevated with palmitoleic acid infusion $(5 \mathrm{mg} / \mathrm{kg} \mathrm{BW})$. However under a hyperglycemic state (IVGTT), palmitoleic acid infusion did not alter serum insulin levels, thus indicating no difference in insulin release by the $\beta$-cells of the pancreas under a stimulated state. These results indicate that palmitoleic acid infusion may alter glucose uptake by peripheral tissues thereby elevating circulating glucose levels. In vitro experiments show that palmitoleate stimulates glucose uptake into C2C12 cells similar to that of insulin [1] and into L6 myotubes in a dose response manner with maximal levels of uptake at $16 \mathrm{~h}$ of incubation [18]. Cao et al. [1] found that this increase in glucose uptake was not associated with changes in Glut1 or Glut4 proteins. Dimopoulus et al. [16] found that palmitoleate induced glucose uptake response was enhanced by elevated plasma membrane abundance of both Glut1 and Glut4 indicating that palmitoleate recruits these transporters from sub cellular locations. Rahman et al. [19] found that SCD1-/- mice, which are unable to produce endogenous palmitoleate, had increased glucose uptake and increased Glut 4 protein levels compared to SCD1+/+ mice. These authors suggest that loss of SCD1 down regulates protein-tyrosine phosphatase that would regulate phosphorylation of insulin receptor (IR) and insulin receptor substrate (IRS-1) to attenuate the insulin response and increases glucose uptake into cells.

The lack of glucose decline during the IC clearly indicates that these sheep regardless of lipid infusion were experiencing insulin resistance. This is probable due to a number of factors including that ruminants are less insulin sensitive compared to monogastrics [5]. The sheep used in this study were 18 months of age and equal physiologically to early twenties humans [20]. However these sheep used in this study had a large amount of adipose tissue and increased amounts of adipose tissue has been shown to increase insulin resistance in similar aged lambs [20]. In physiologically younger ruminants that did not have increased amounts of adipose tissue a similar insulin challenge resulted in a 50\% reduction in plasma glucose compared to baseline values [21]. However, in similar aged lambs insulin resistance was noted in a very lean state ( $5 \%$ Body fat) and this insulin resistance increased as lambs increased in body fat ( $20 \%$ body fat) due to maternal obesity [17].

Palmitoleic acid has been proposed to function as a lipokine, a fatty acid that stimulates muscle insulin action [1]. These authors reported exogenous administration of tripalmitoleate decreased lipogenesis in liver and increased insulin sensitivity in skeletal muscle of mice. Yang et al. [22] orally fed $\mathrm{KK}-\mathrm{A}^{\mathrm{y}}$ mice, a model for type 2 diabetes, 300 $\mathrm{mg} / \mathrm{kg}$ of palmitoleic acid and found that it improved hyperglycemia by increasing insulin sensitivity. It appeared to work in part by down regulating pro-inflammatory gene expression (TNFa and resistin) and by reducing hepatic triglyceride levels. In humans, circulating palmitoleic acid levels are strongly related to insulin sensitivity as measured by oral glucose tolerance test and euglycemic clamp [23] or C-peptide concentrations [24]. Bergman et al. [25] reported that unesterified palmitoleic acid level in plasma was positively related to insulin sensitivity in normal humans but not in subjects with type 1 diabetes. Subjects with type 1 diabetes had lower levels of circulating unesterified palmitoleic acid, which suggests that palmitoleic acid promotes insulin sensitization. Knockout of the SCD-1 gene in mice reduces adipose tissue deposition, increases insulin sensitivity, and makes animals resistant to diet-induced weight gain [26]. SCD1-/mice had lower fasting insulin and glucose levels on a normal chow diet but glucose tolerance was improved. 
The results of this research show that palmitoleic acid infusion increases circulating glucose levels in normal conditions and under glucose challenge; whereas circulating insulin levels were increased with palmitoleic acid infusion during insulin challenge. The changes in plasma glucose levels with palmitoleic acid infusion could result from changes in uptake by peripheral tissues possibly mediated through down regulation of glucose transporters. The increase in insulin by palmitoleic acid infusion under insulin challenge appears related to stimulation of insulin release in islets of Langerhans. Gravena et al. [27] reported increased insulin release from rat and human islets in batch incubations with exposure to palmitoleate and different levels of glucose for 90 minutes. Acute exogenous administration of palmitoleic acid in obese sheep can alter glucose and insulin dynamics. Additional research is needed to examine how long-term exposure to palmitoleic acid regulates glucose and insulin levels in vivo. In conclusion, palmitoleic acid infusion results in immediate uptake and clearance of serum palmitoleic acid, increases plasma glucose levels, and alters circulating insulin levels. Additional research is needed to examine how long-term exposure to palmitoleic acid regulates glucose and insulin levels in vivo.

\section{Acknowledgements}

Technical Contribution No. 6199 of the Clemson University Experiment Station. This material is based upon work supported by the NIFA/USDA, under project number SC-1700439.This project was funded in part by USDA-NIFA grant award 2010-38942-20745.

\section{References}

1. Cao H, Gerhold K, Mayers JR, Wiest MM, Watkins SM, et al. (2008) Identification of a lipokine, a lipid hormone linking adipose tissue to systemic metabolism. Cell 134: 933-944.

2. Burns TA, Kadegowda AK, Duckett SK, Pratt SL, Jenkins TC (2012) Palmitoleic (16:1 cis-9) and cis-vaccenic (18:1 cis-11) acid alter lipogenesis in bovine adipocyte cultures. Lipids 47: 1143-1153.

3. Burns TA, Duckett SK, Pratt SL, Jenkins TC (2012) Supplemental palmitoleic (C16:1 cis-9) acid reduces lipogenesis and desaturation in bovine adipocyte cultures. J Anim Sci 90: 3433-3441.

4. Kahn CR (1978) Insulin resistance, insulin insensitivity, and insulin unresponsiveness: a necessary distinction. Metabolism 27: 1893-1902.

5. Kaske M, Elmahdi B, von Engelhardt W, Sallmann HP (2001) Insulin responsiveness of sheep, ponies, miniature pigs and camels: results of hyperinsulinemic clamps using porcine insulin. J Comp Physiol B 171: 549-556.

6. Duhlmeier R, Hacker A, Widdel A, von Engelhardt W, Sallmann HP (2005) Mechanisms of insulin-dependent glucose transport into porcine and bovine skeletal muscle. Am J Physiol Regul Integr Comp Physiol 289: R187-197.

7. Liu S, Baracos VE, Quinney HA, Clandinin MT (1994) Dietary omega-3 and polyunsaturated fatty acids modify fatty acyl composition and insulin binding in skeletal-muscle sarcolemma. Biochem J 299 : 831-837.

8. Behme MT (1996) Dietary fish oil enhances insulin sensitivity in miniature pigs. J Nutr 126: 1549-1553.

9. Ponnampalam EN, Sinclair AJ, Egan AR, Blakeley SJ, Li D, et al. (2001) Effect of dietary modification of muscle long-chain n-3 fatty acid on plasma insulin and lipid metabolites, carcass traits, and fat deposition in lambs. J Anim Sci 79: 895-903.
10. Taouis M, Dagou C, Ster C, Durand G, Pinault M, et al. (2002) N-3 polyunsaturated fatty acids prevent the defect of insulin receptor signaling in muscle. Am J Physiol Endocrinol Metab 282: E664-671.

11. Gingras AA, White PJ, Chouinard PY, Julien P, Davis TA, et al. (2007) Long-chain omega-3 fatty acids regulate bovine whole-body protein metabolism by promoting muscle insulin signalling to the Akt-mTORS6K1 pathway and insulin sensitivity. J Physiol 579: 269-284.

12. Cartiff SE, Fellner V, Eisemann JH (2013) Eicosapentaenoic and docosahexaenoic acids increase insulin sensitivity in growing steers. J Anim Sci 91: 2332-2342.

13. Park PW and Goins RE (1994) In situ preparation of FAME for analysis of fatty acid composition in foods. J Food Sci 59: 1262-1266

14. Duckett SK, Neel JP, Lewis RM, Fontenot JP, Clapham WM (2013) Effects of forage species or concentrate finishing on animal performance, carcass and meat quality. J Anim Sci 91: 1454-1467.

15. Persson XM, Blachnio-Zabielska AU, Jensen MD (2010) Rapid measurement of plasma free fatty acid concentration and isotopic enrichment using LC/MS. J Lipid Res 51: 2761-2765.

16. Long NM and Schafer DM (2013) Sex effects on plasma leptin concentrations in newborn and postnatal beef calves. Prof Anim Sci 29:601-605

17. Long NM, Shasa DR, Ford SP, Nathanielsz PW (2012) Growth and insulin dynamics in two generations of female offspring of mothers receiving a single course of synthetic glucocorticoids. Am J Obstet Gynecol 207: 203.

18. Dimopoulos N, Watson M, Sakamoto K, Hundal HS (2006) Differential effects of palmitate and palmitoleate on insulin action and glucose utilization in rat L6 skeletal muscle cells. Biochem J 399: 473-481.

19. Rahman SM, Dobrzyn A, Lee SH, Dobrzyn P, Miyazaki M, et al. (2005) Stearoyl-CoA desaturase 1 deficiency increases insulin signaling and glycogen accumulation in brown adipose tissue. Am J Physiol Endocrinol Metab 288: E381-387.

20. Long NM, George LA, Uthlaut AB, Smith DT, Nijland MJ, et al. (2010) Maternal obesity and increased nutrient intake before and during gestation in the ewe results in altered growth, adiposity, and glucose tolerance in adult offspring. J Anim Sci 88: 3546-3553.

21. Long NM, Prado-Cooper MJ, Krehbiel CR, Wettemann RP (2010) Effects of nutrient restriction of bovine dams during early gestation on postnatal growth and regulation of plasma glucose. J Anim Sci 88: 3262-3268.

22. Yang G, Li L, Fang C, Zhang L, Li Q, et al. (2005) Effects of free fatty acids on plasma resistin and insulin resistance in awake rats. Metabolism 54: 1142-1146.

23. Stefan N, Kantartzis K, Celebi N, Staiger H, Machann J, et al. (2010) Circulating palmitoleate strongly and independently predicts insulin sensitivity in humans. Diabetes Care 33: 405-407.

24. Kurotani K, Sato M, Ejima Y, Nanri A, Yi S, et al. (2012) High levels of stearic acid, palmitoleic acid, and dihomo- $\hat{I}^{3}$-linolenic acid and low levels of linoleic acid in serum cholesterol ester are associated with high insulin resistance. Nutr Res 32: 669-675.

25. Bergman BC, Howard D, Schauer IE, Maahs DM, Snell-Bergeon JK, et al. (2013) The importance of palmitoleic acid to adipocyte insulin resistance and whole-body insulin sensitivity in type 1 diabetes. J Clin Endocrinol Metab 98: E40-50.

26. Ntambi JM, Miyazaki M, Stoehr JP, Lan H, Kendziorski CM, et al. (2002) Loss of stearoyl-CoA desaturase-1 function protects mice against adiposity. Proc Natl Acad Sci U S A 99: 11482-11486.

27. Gravena C, Mathias PC, Ashcroft SJ (2002) Acute effects of fatty acids on insulin secretion from rat and human islets of Langerhans. J Endocrinol 173: $73-80$. 